\title{
Discriminatory Behavior among People Living with Human Immunodeficiency Virus/Acquired Immune Deficiency Syndrome against Adherence to Antiretroviral Treatment
}

\author{
Nur Azizah Indriastuti*, Ririn Ayuningtyas \\ School of Nursing, Faculty of Medicine and Health Sciences, Universitas Muhammadiyah Yogyakarta, Yogyakarta, Indonesia
}

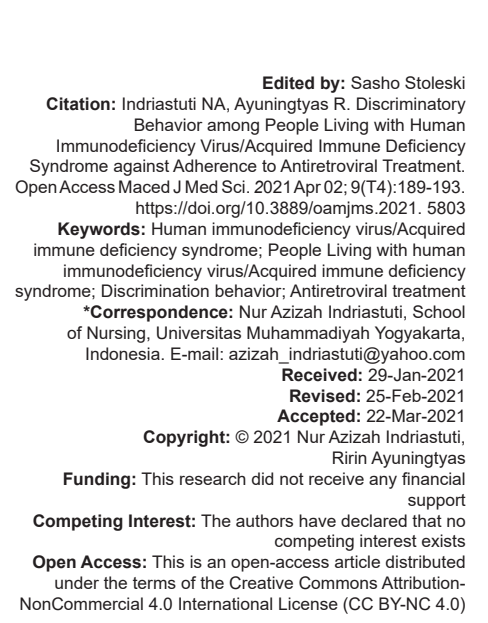

Abstract

BACKGROUND: Globally, human immunodeficiency virus/acquired immune deficiency syndrome (HIV/AIDS) is a serious health issue, as the number of sufferers increases from year to year. As there are many HIV/AIDS cases, antiretroviral treatment (ART) regimens' success is determined by the high adherence of people living with HIVIAIDS (PLWHA) undergoing a treatment regimen. PLWHA adherence in undergoing ART regimens can be influenced by discriminatory behavior toward them.

AIM: This study aims to identify discriminatory behavior in PLWHA toward adherence to ART in Yogyakarta.

METHODS: This research used a qualitative method with a phenomenology approach. The collection of data was carried out through interviews and observation. Participants totaling seven people were determined by purposive sampling. The data validity employed source triangulation and checked the data back to the participants. Analysis of data was by comparing among categories, marking, and describing descriptively.

RESULTS: The results showed that PLWHA got discriminatory behavior around them during ARV treatment, which came from the attitude of health workers and unpleasant experiences from the environment, but this discriminatory behavior did not affect PLWHA adherence to ARV treatment.

CONCLUSION: Discriminatory behavior from health workers and the environment around PLWHA did not affect PLWHA adherence during ARV treatment.

\section{Introduction}

The acquired immune deficiency syndrome (AIDS) is a global health epidemic caused by the human immunodeficiency virus (HIV) [1]. It is estimated that the world's population suffering from HIVIAIDS is around 36.7 million people [2]. Indonesia's total number of HIV/AIDS cases in 2018 was around 640,443 people [3]. The transmission of HIVIAIDS has spread over widely to all provinces in Indonesia, one of which is the province of Yogyakarta. Yogyakarta province was ranked $9^{\text {th }}$ concerning the HIVIAIDS problem [4]. For treatment, people living with HIVIAIDS (PLWHA) receive antiretroviral treatment (ART). ART has been an essential part of PLWHA's HIVIAIDS prevention efforts to reduce disease burden and increase life expectancy [5].

Many studies have shown that the percentage of patients remaining in care after ART initiation was low [6]. The most frequent cause for treatment failure is non-adherence to ART [7]. There is an association between discrimination and adherence to ART [8]. PLHWA's stigma and prejudice affect PLWHA in initiating
ARV therapy and adhering to ARV therapy due to the sense of inferiority felt after discriminatory behavior [9]. One of the community foundations in Yogyakarta engaged in the health sector, primarily related to HIV/ AIDS issues, is the Victory Plus foundation. Based on a preliminary survey at the Yogyakarta Victory Plus Foundation, it was found that 3908 people living with HIV underwent ARV treatment, and 583 people living with HIV adhered to treatment. Based on this incident, the researchers were interested in examining the disclosure of HIVIAIDS status to PLHIV adherence to ARV treatment.

\section{Methods}

This study used qualitative methods with a phenomenological approach. This research was conducted in February-April 2019. In this study, the participant inclusion criteria were PLWHA who were obedient and never missed the current ARV treatment, were willing to be research informants, and could 
communicate verbally. The total number of respondents in this study was seven people because the data had reached data saturation when they were in the $7^{\text {th }}$ participant. Data retrieval was done by in-depth interviews and unstructured observation. The focus of observation would develop during the interview. The data's validity was carried out using source triangulation, namely, toward representatives of participant families, peer support, and VCT (Voluntary Counselling Test) service doctors at the community health center and rechecking data with participants. Data analysis was performed by comparing one category with the other, marking in each unit, and describing descriptively the essence of the phenomenon been obtained. The study was conducted at the Victory Plus Yogyakarta foundation. This research has passed the ethical test by the Faculty of Medical and Health Sciences, Universitas Muhammadiyah Yogyakarta ethics committee with ethics number 029/ EP-FKIK-UMY/I/2019.

\section{Results}

\section{Characteristics of participants (Table 1)}

The first participant was a woman, aged 37 years when taking data, had married status, had one child, and lived with husband and child. The participant's job was a private employee. The participant has been diagnosed with HIVIAIDS Stage 3 since 2017 and has been undergoing first-line ARV treatment from 2017 to the present.

The second participant was a woman and 42 years old when data were taken. The participant's status was married, but her husband died in 2015. She had two children and lived with parents and children. She worked as a peer supporter at the Victory Plus Foundation. The participant has been diagnosed with HIVIAIDS Stage 2 since 2008, and the first child has been diagnosed with HIVIAIDS Stage 4 since 2008, while the second child was negative. Participants underwent first-line ARV treatment from approximately 2010 to the present.

The third participant was a man and aged 38 years when collecting data. He had married status but divorced already, had children, but the children were negative and lived alone. He has been diagnosed with HIVIAIDS Stage 3 status since 2014 and has been undergoing first-line ARV treatment since 2014. The participant's job was a private employee.

The fourth participant was a woman and aged 48 years at the time of data collecting, had married status, had three children, and lived with her children. The participant has been diagnosed with HIVIAIDS Stage 2 since 2009 and started her first-line ARV therapy regimen in 2010. The participant's job was peer support at the Victory Plus Foundation.

The fifth participant was a 30-year-old man when taking data, not married, and lived alone. Participants were diagnosed with stage 4 HIVIAIDS in 2014 and started first-line ARV therapy in 2014. The work of the participants is peer support at the Victory Plus Foundation.

The sixth participant was a 52-year-old man when data taken, had the status of being married, and had children, but now lived alone. The participant was diagnosed with Stage 4 HIVIAIDS in 2009 and started first-line ARV treatment from 2011 until now. The occupation of the participants was peer support at the Victory Plus Foundation.

The seventh participant was a 36-year-old man when data taken, not married, and lived alone. He has been diagnosed with HIVIAIDS since 2010 and started his first-line ARV therapy regimen from 2010 until now. The participant's job was a private employee.

In this study, researchers found a theme related to the adherence of PLWHA in undergoing ART regimens, namely, discriminatory behavior against ARV treatment. Discriminatory behavior against ARV treatment included health workers' attitudes during ARV treatment and unpleasant experiences from the environment during ARV treatment.

\section{treatment \\ Attitudes of health workers during ARV}

Most participants received unfavorable treatment by health workers in health services during ARV treatment. It was supported by the following interview excerpts:

So once at Hospital $\mathrm{X}$ told me to take control and take medicine, "oh this is the ODHA, later

Table 1: Characteristics of participants

\begin{tabular}{|c|c|c|c|c|c|c|c|}
\hline Characteristics & P1 & P2 & P3 & P4 & P5 & P6 & P7 \\
\hline Gender & Female & Female & Male & Female & Male & Male & Male \\
\hline Age & 37 years & 42 years & 38 years & 48 years & 30 years & 52 years & 36 years \\
\hline Address & Yogyakarta & Yogyakarta & Solo & Yogyakarta & Ciamis & Klaten & Yogyakarta \\
\hline Employment & Private employees & Private employees & Private employees & Private employees & Private employees & Private employees & Private employees \\
\hline Status & Married & Married & Married & Married & Not married & Married & Not married \\
\hline HIV/AIDS stage long & Stadium 3 & Stadium 2 & Stadium 3 & Stadium 2 & Stadium4 & Stadium4 & Stadium 1 \\
\hline ARV therapy & 2017-now & 2010- now & 2014- now & 2010- now & 2014- now & 2011- now & 2014- now \\
\hline Types of ARVs & Line 1 & Line 1 & Line 1 & Line 1 & Line 1 & Line 1 & Line 1 \\
\hline CD4 levels and viral & CD4 252 cell/ $/ \mu \mathrm{L}$, & CD4 926 cell/ $/ \mu \mathrm{L}$, & CD4 926 cell/ $\mu \mathrm{L}$, & CD4 468 cell/ $/ \mu \mathrm{L}$, & CD4 439 cell/ $/ \mu \mathrm{L}$ & CD4 482 cell/ $/ \mu \mathrm{L}$ & CD 4500 cell/ $/ \mu \mathrm{L}$ \\
\hline load within 3 months & $\mathrm{VL}<40$ copy/cell & VL undetected & VL undetected & $\mathrm{VL}<40$ copy/cell & VL undetected & VL undetected & VL undetected \\
\hline
\end{tabular}


the PLWHA here is this place is this place..., this corner is that." (participant 1)

"After my demands were granted, the treatment of the medical team at the poly to me was very different from the previous ones who were friendly if I took medicine, I was given an education, so it was different until I moved out of town." (participant 3)

"In the beginning yes, but yes I understand their attitudes ..." (participant 6)

"Sometimes, we come to the police to take drugs or take sudden action, why are we the backmost of love ..." (participant 7)

Based on this, it is known that the unpleasant experiences of health workers experienced by participants during treatment included queuing for drug taking and actions to patients given in the final sequence, lack of privacy regarding patient status data, and health workers were still afraid of direct contact with PLWHA.

Unlike the previous four respondents, this study also revealed that respondents did not experience unpleasant attitudes from health workers. It was supported by an excerpt from the interview results, as follows:

"In terms of discrimination when I took medicine, so far, I have not, sis,..." (participant 2)

"So far, when I took medicine, the health worker was fine, sis to me." (participant 4)

"I personally have never experienced discrimination like that." (participant 5)

Based on this, it is known that respondents who either experienced discrimination or not when accessing ARV treatment continued to undergo ARV treatment and accessed ARV in health services.

The following are the results of source triangulation conducted with professional staff, namely, VCT service doctors who worked at the Gedong Tengen Community Health Center regarding the unpleasant behavior experienced by PLWHA when accessing drugs in health services:

Doctor: "Well, for that matter, because there are many patients at the Community Health Center here, sis. So, it is really for a limited time, and we really cannot go for a long consultation unless the doctor is not full to provide consultation services about drugs. However, taking the patient's medicine here is put at the end. For the patient's data that other parties can access, it should be, and as far as I think, it has never been... Actually, for health services, be it from hospitals or Community Health Center that can and receive HIV services; usually, it is rare, yeah for discrimination, and it should not exist. Maybe, it happens in hospitals or health centers that are not used to HIV patients. So, they are afraid that when they want to do health services, what will the term, be lazy to hold, lazy like that.., so it still needs to some services for which there are no HIV services or to which they already need to be exposed again for about HIV...."

\section{Unpleasant experiences from the environment during ARV treatment}

In this study, most participants during the ARV treatment regimen experienced unpleasant experiences from the environment. It was supported by an excerpt from the interview results, as follows:

"I was told I could not work there anymore, yeah..." (participant 1 )

"Surely, those mothers ask your child why, what kind of pain is that, and it makes me embarrassed and afraid to leave the house." (participant 2)

"At that time, I was given two choices, I wanted to leave, or I opted out ..." (participant 3)

"So, the drinks or food that I have touched they do not want to eat, sis..." (participant 4)

"Was also expelled from work ..." (participant 5)

"Their attitude is bad towards me ..." (participant 6)

In this study, the experience of one participant who did not experience unpleasant things from the surrounding environment was also found. It was supported by the following interview results:

"As for the discrimination from the environment during treatment, it is not really that bad..." (participant 7)

In this study, participants experienced less pleasant experiences from the surrounding environment during treatment, namely, being dismissed from their jobs because they often had permission to take ARV drugs to health services. Based on the participants' experience, sometimes, people around them often asked why they often took drugs, what pain, and even when they knew the participants' status, many chose to stay away and leave.

\section{Discussion}

In this study, adherence to PLWHAin undergoing ART regimens was influenced by discriminatory behavior from health workers and the environment. Discriminatory attitudes from health workers experienced by participants comprised queuing for drugs at the end, fear of contact with PLWHA, especially when giving action, less friendly in services, especially medical education, and so on. The attitudes of health workers toward PLHIV included fear of contact with HIV patients and not wanting to give intervention to HIV patients. In this study, there were also some participants who, during their ARV treatment, had never experienced discriminatory behavior from health workers.

Participants who either received discrimination or not from health workers in this study continued to 
follow a routine treatment regimen. It contrasts with research that stigmatizing attitudes and discrimination by health workers cause their fear for PLWHA to be late in accessing treatment or not wanting ARV treatment services [10]. The fear of the stigma faced by people using ARVs resulted in failure to stick to therapy so that patients preferred remote treatment services rather than near their homes, putting them at risk of irregularly taking ARVs. It was because they were afraid to be seen by friends and neighbors. Besides, this stigma made them hide their HIV status, so they did not want to tell others about their HIV status [9].

Factors that hinder treatment adherence are poor knowledge about treatment, lack of patient follow-up, dissatisfaction about the quality of ART services provided by health workers, lack of confidentiality among health workers in handling HIV patients, long waiting times in health facilities, and fear of health workers affected the infection from the patient [11].

Most participants had unpleasant experiences in the environment during their ARV therapy regimen. The experience encompassed work dismissal because the participants often asked permission from work to take ARV drugs at health services. The neighbors and neighborhood friends did not want to hang out with PLWHA, and they were afraid of being infected. This made the neighbors' attitude were less friendly towards PLWHA. PLWHA stigmatized society and environment, such as being excluded, receiving a rejection from people in the PLWHA environment, and not being accepted in the workplace. PLHWA can be fear or be stigmatized by the public through acts of discrimination, abuse, or ostracism [10]. Stigma and discrimination against PLWHA could come from colleagues, friends, and society. PLWHA hid the HIVIAIDS status due to the stigma experienced. They were silent, sad, hopeless, anxious, and scared of revealing their HIV status, which could negatively impact their quality of life [12]. However, some participants did not experience discrimination in their surroundings.

In this study, it was also known that both participants who experienced unpleasant experiences from the environment and not continued to adhere to treatment and routinely undergo therapy regimens. It is different from previous research, which stated that discriminatory behavior significantly affected PLWHA adherence to treatment. HIV-related stigma may be taking a toll on HIV prevention, treatment, and the care of people living with HIV [13]. The stigma and discrimination that PLWHA has experienced affected PLWHA in starting ARV therapy and adherence to ARV therapy. It was due to the feeling of inferiority felt after getting discriminatory behavior. Social factors related to ARV adherence were fear of using health services when taking ARV drugs, fear of being seen interacting with health care workers providing HIV services, fear of stigma and discrimination from society, and fear of being embarrassed by the community if their HIV status was revealed [14].

On the other hand, factors that support PLWHA in taking ARV drugs are family and friends. Adherence to taking ARVs is strongly influenced by the support of the people closest to people living with HIV, especially wives. Various forms of family support in increasing ARV adherence are such as always reminding husbands every time they take medication and helping to prepare ARVs on time [15].

\section{Conclusion}

Discriminatory behavior from health workers and the environment around PLWHA did not affect PLWHA adherence during ARV treatment. Future researchers should look for other factors causing nonadherence of PLWHA to ARV therapy and how health workers and the community may minimize stigma and discrimination.

\section{Acknowledgments}

The authors thank all respondents who were participating and giving information for accomplishing research data.

\section{References}

1. Liu H, Zhao M, Ren J, Qi X, Sun H, Qu L, et al. Identifying factors associated with depression among men living with HIVI AIDS and undergoing antiretroviral therapy: A cross-sectional study in Heilongjiang, China. Health Qual Life Outcomes. 2018;16(1):190. https://doi.org/10.1186/s12955-018-1020-x PMid:30231885

2. United Nations Programme on HIV/AIDS. Global AIDS Monitoring 2018, Europe: United Nations Programme on HIVIAIDS; 2017. https://doi.org/10.1093/oso/9780190672676.003.0014

3. Kementerian Kesehatan Republik Indonesia. Situasi umum HIVAIDS Tahun 2018. Jakarta: Kementerian Kesehatan Republik Indonesia; 2018. https://doi.org/10.36407/akurasi.v2i2.177

4. Dinas Kesehatan Provinsi Yogyakarta. Laporan Profil Kesehatan Provinsi DI Yogyakarta Tahun 2017. Yogyakarta: Dinas Kesehatan Provinsi Yogyakarta; 2017. https://doi.org/10.22146/ jkesvo.50428

5. Than PQ, Tran BX, Nguyen CT, Truong NT, Thai TP, Latkin CA, et al. Stigma against patients with HIVIAIDS in the rapid expansion of antiretroviral treatment in large drug injectiondriven HIV epidemics of Vietnam. Harm Reduct J. 2019;16(1):6. https://doi.org/10.1186/s12954-019-0277-7

PMid:30654814

6. Bucciardini R, Fragola V, Abegaz T, Lucattini S, Halifom A, 
Tadesse $\mathrm{E}$, et al. Retention in care of adult HIV patients initiating antiretroviral therapy in Tigray, Ethiopia: A prospective observational cohort study. PLoS One. 2015;10(9):e0136117. https://doi.org/10.1371/journal.pone.0136117

PMid:26340271

7. Heestermans T, Browne JL, Aitken SC, Vervoort SC, KlipsteinGrobusch K. Determinants of adherence to antiretroviral therapy among HIV-positive adults in sub-Saharan Africa: A systematic review. BMJ Glob Health. 2016;1(4):e000125. https://doi. org/10.1136/bmjgh-2016-000125

PMid:28588979

8. Galvan FH, Bogart LM, Klein DJ, Wagner GJ, Chen YT. Medical mistrust as a key mediator in the association between perceived discrimination and adherence to antiretroviral therapy among HIV-positive Latino men. J Behav Med. 2017;40(5):784-93. https://doi.org/10.1007/s10865-017-9843-1 PMid:28337560

9. Mhode M, Nyamhanga T. Experiences and impact of stigma and discrimination among people on antiretroviral therapy in Dar es Salaam: A qualitative perspective. AIDS Res Treat. 2016;2016:7925052. https://doi.org/10.1155/2016/7925052 PMid:27110395

10. Fido NN, Aman M, Brihnu Z. HIV stigma and associated factors among antiretroviral treatment clients in Jimma town, Southwest Ethiopia. HIV AIDS (Auckl). 2016;8:183-93. https:// doi.org/10.2147/hiv.s114177

PMid:27920581

11. Azia IN, Mukumbang FC, van Wyk B. Barriers to adherence to antiretroviral treatment in a regional hospital in Vredenburg, Western Cape, South Africa. Southern Afr J HIV Med. 2016;17(1):476. https://doi.org/10.4102/hivmed.v17i1.476 PMid:29568618

12. Olusola OD, Fredrick OO, Otovwe A, Abideen OO. (2017). HIV/AIDS-related stigmatization and discrimination and coping strategies among people living with HIVIAIDS (PLHIV) at the anti-retroviral (ARV) clinic, University College Hospital Ibadan, Nigeria. J AIDS HIV Res. 2017;9(11):209-19. https://doi. org/10.5897/jahr2017.0451

13. Kamau TM. Post antiretroviral era: An examination of HIVstigma and discrimination in Nyeri and Nyandarua counties in Kenya. Int J Health Sci Res. 2016;6(6):277-85.

14. Kementerian Kesehatan Republik Indonesia. Laporan Perkembangan HIV-AIDS and Penyakit Infeksi Menular Seksual (PIMS) Triwulan 1 Tahun 2017. Jakarta: Kementerian Kesehatan Republik Indonesia; 2017. https://doi.org/10.7454/ epidkes.v1i2.1805

15. Astuti W, Rayasari F. The Sexual Experience Of a Couple With Hiv With a Negative Hiv Maintenance Status At Prof. Sulianti Saroso Infectious Desease Hospital. Indonesia J Nurs Pract. 2017;1(2):32-43, https://doi.org/10.18196/ijnp.1259 